Theatre Research in Canada

Recherches théâtrales au Canada

\title{
Dramaturgy For Digital Natives
}

\section{Justin A. Blum}

Volume 39, Number 1, 2018

URI: https://id.erudit.org/iderudit/1055471ar

DOI: https://doi.org/10.7202/1055471ar

See table of contents

Publisher(s)

Graduate Centre for the Study of Drama, University of Toronto

ISSN

1196-1198 (print)

1913-9101 (digital)

Explore this journal

Cite this document

Blum, J. (2018). Dramaturgy For Digital Natives. Theatre Research in Canada / Recherches théâtrales au Canada, 39(1). https://doi.org/10.7202/1055471ar

All Rights Reserved (C Theatre Research in Canada / Recherches théâtrales au Canada, 2018
This document is protected by copyright law. Use of the services of Érudit (including reproduction) is subject to its terms and conditions, which can be viewed online.

https://apropos.erudit.org/en/users/policy-on-use/
This article is disseminated and preserved by Érudit.

Érudit is a non-profit inter-university consortium of the Université de Montréal, Université Laval, and the Université du Québec à Montréal. Its mission is to promote and disseminate research.

https://www.erudit.org/en/ 


\section{Dramaturgy For Digital Natives}

JUSTIN A. BLUM

Many of the discussions with my fellow contributors to this Forum aptly identify ways in which liberal arts education in general, and theatre and drama curricula within the liberal arts in particular, are already providing university undergraduates with skills they will need for successful lives and careers in the twenty-first century. I'm more than happy to embrace the idea that our programs and departments should be better recognized by administrators and the public for the things we already do well. I would nevertheless advocate at least one important curricular reform that might be made to many of our programs in drama and theatre studies: dramaturgy, in the many places where it is not already the case, should be made part of the core of any university education in theatre and drama. Making this practice as integral to our curricula as courses in acting, directing, or design will not only help to prepare our students for the professional careers in the theatre that a small number of them will have, but will also provide invaluable skills for navigating a culture in which information technologies have left us all on the precipice of fundamental shifts in how we work, live, and come together to create political communities.

Those of us who have practiced and taught dramaturgy in Canadian universities are accustomed to explaining the word, and what it is that those of us who call ourselves "dramaturgs" do in both rehearsal rooms and institutional contexts. Individual Canadian practitioners and teachers have participated in the wider dissemination of this role and set of practices in North America since it began to emerge in the I970s, incubated in places like the Yale School of Drama which adopted the model of the "critic/dramaturg" as it developed in the German theatre (Borreca 58). To date, though, the presence or absence of dramaturgy courses in our universities has largely depended on whether a scholar or artist with knowledge of the practice happens to be employed at a given institution. This may be in part related to an ongoing sense of definitional uncertainty among dramaturgs and about dramaturgy: to date no single definition of the role or set of practices has emerged, and dramaturgs themselves have often resisted developing one as a matter of principle. As Geoffrey Proehl points out, the existence of an ongoing "conversation around this attribute/role/function we call 'dramaturgy' invites us to think and rethink the role of consciousness in the rehearsal hall and to think and rethink how together we make this thing we call theatre" (136). While this definitional slipperiness might make dramaturgy harder than other practices to fix into curricula and prioritize in hiring lines, I suggest that is precisely what makes it so urgent for our contemporary moment. The sense that the contours of the role of the dramaturg and the skills and techniques she uses are not entirely defined can lead to the marginalization of the position in academic programs, but can also offer a powerful potential for dramaturgy as a part of a curriculum geared for students facing an economic and cultural future in which they will likely have to reinvent themselves on multiple occasions. Moreover, those aspects of the practice that are more fixed, particularly the traditional association of dramaturgy with the conduct, curation, and mobiliza- 
tion of research for the use of other artists and audience members, resonate strongly with the emergent problems of an Information Age.

The cultural and technological landscape in which information circulates has definitively changed in less than a generation, and most of our current students have spent their entire lives living in a world where information is both superabundant and always potentially suspect. Legal scholar Nathan Persily argues, in a much-discussed recent essay entitled "Can Democracy Survive the Internet?", that this transition has potentially profound consequences for the stable liberal-democratic order that has characterized post-war Western societies. With traditional barriers to the spread of information like cost and access to distribution channels now diminished, if not entirely eliminated, by the ubiquity of the internet, Persily argues that "established institutions - especially the mainstream media and political-party organizations - [have] already lost most of their power, both in the United States and around the world," with outsider candidates and causes "rid[ing] a global technological wave that has accompanied deep dissatisfaction with legacy institutions both inside and outside politics" (64). Misleading and outright-false information circulates through social media so rapidly that it has had real political and social effects before it could be debunked. If this isn't an entirely novel situation - the adage about a lie being half-way around the world while the truth is lacing its boots is old enough to have been erroneously attributed to Pope, Twain, and Churchill - what seems genuinely new in the current cultural moment is that the bars to entry for publicizing information have shifted, and media companies can no longer be counted on to "have as their lodestar the fostering of a well-informed and civically minded electorate" (74). Training in dramaturgy might help our drama students to survive and thrive as citizens in this world not in spite of the evident slipperiness of the position, but because of it. Having to explain and conceptualize dramaturgy even while practicing it has the potential to unsettle comfortable definitions about how theatrical labour is defined, in much the same way that non-theatrical occupations like "journalist," "politician," and even "citizen" are currently subject to uncertainty and debate.

Importantly, those facets of the dramaturg's job that are widely understood include "evaluating scripts and writing program notes, [...] conduct [ing] research for directors and designers, writ[ing] articles for subscriber newsletters, [and] compos[ing] study guides": in short, locating fact-based knowledge and conveying it clearly to fellow artists and audiences (Borreca 58). There are alternative models of dramaturgical practice, particularly relevant given how much contemporary theatre is "defined by new media technologies and new perceptual habits," and good reasons to resist defining the dramaturg solely as a librarybound font of factual information (Lehman and Primavesi 3). However, locating good-quality, factual information and informed criticism about a playtext and historical or contextual issues brought up by the text is almost always part of a dramaturg's remit. Crucially, because research materials that are insufficiently curated risk being unread by audience members or being ignored by collaborators, one of the primary skills that a student of dramaturgy must learn is how to carefully select and pass on information by considering its potential utility to directors, actors, designers, and audience members, who each need different sorts of information, and need it presented differently. Training "to dramaturg" as an active process and a critical mindset, one that embraces "the ability to define, to offer context" through the martialing of information and the asking of questions, is training to think about how infor- 
mation is encountered and put to work across different situations (Lang 6). The kind of materials that dramaturgs produce represent a directly-applied version of the critical thinking and research that a broad liberal arts education aims to instill, tools that will be of unquestionable value to students who will need navigate a future as workers and citizens in which they'll have to constantly ask themselves questions about the factuality of facts and the veracity of nearly every form of media they encounter. By training to locate, evaluate, and make information and critical analyses useful for others within a theatrical production process in a position that they will need to continually justify and define, students prepare to see this process at work in other media and ask important questions about what they are being told, by whom, and why. Whether they find themselves working in a theatre or not, there may be no one better positioned to surf the waves of change in the Information Age than a dramaturg.

\section{Works Cited}

Borreca, Art. "Dramaturging New Play Dramaturgy: The Yale and Iowa Ideals." Dramaturgy in American Theatre: A Source Book. Ed. Susan Jonas, Geoff Proehl, and Michael Lupu. New York: Harcourt Brace, 1997. 56-69. Print.

Lang, Theresa. Essential Dramaturgy: The Mindsent and Skillset. London: Routledge, 20I7. Print.

Lehman, Hans-Thies and Patrick Primavesi. "Dramaturgy On Shifting Grounds.” Performance Research I4.3 (2009): 3-6. Print.

Persily, Nathaniel. "Can Democracy Survive the Internet?” Fournal of Democracy 28.2 (April 2017): 6376. Print.

Proehl, Geoffrey S. "The Image Before Us: Metaphors for the Role of the Dramaturg in American Theatre." Dramaturgy in American Theatre: A Source Book. Ed. Susan Jonas, Geoff Proehl, and Michael Lupu. New York: Harcourt Brace, 1997. 124-36. Print. 